\title{
HMGA2/LPP Short Fusion Protein
}

National Cancer Institute

\section{Source}

National Cancer Institute. HMGA2/LPP Short Fusion Protein. NCI Thesaurus. Code C99421.

A fusion protein encoded by the HMGA2/LPP fusion gene. This protein is comprised of the AT-hook DNA binding domain of the high mobility group protein HMGI-C fused to LIM domains 2 and 3 of the C-terminal portion of the lipoma-preferred partner protein. 